\title{
Fonksiyonellendirilmiş Alümina ve Silika Katkılı Kevlar-Cam Elyaf/Epoksi Reçineli Hibrit Kompozitlerin Cam ve Kevlar Yüzeylerine Uygulanan Darbe Enerjilerinin Darbe Davranışlarına Etkisinin İncelenmesi
}

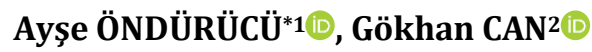 \\ ${ }^{1}$ Süleyman Demirel Üniversitesi, Mühendislik Fakültesi, Makina Mühendisliği Bölümü, 32260, Isparta, Türkiye \\ ${ }^{2}$ Isparta Belediye Başkanlığı, Fen İşleri Müdürlügü, 32200, Isparta, Türkiye
}

(Alınıș / Received: 25.10.2019, Kabul / Accepted: 01.11.2020, Online Yayınlanma/ Published Online: 20.12.2020)

\author{
Anahtar Kelimeler \\ Cam elyaf, \\ Kevlar, \\ Alümina, \\ Silika, \\ Darbe davranışı, \\ Hibritkompozit
}

\begin{abstract}
Özet: Tüm kompozitler kullanım yerlerine göre çeşitli darbelere maruz kalabilirler. Darbe sonrası malzemede oluşan hasar; darbe enerjisine, kullanılan katkı malzemesi ve oranlarına, vurucu uç özelliklerine ve darbenin uygulandı̆̆ yüzey gibi faktörlere bağlı olarak değişmektedir. Bu çalışmada, alümina ve silika katkılı kevlar-cam elyaf/epoksi hibrit kompozit plakalarının kevlar ve cam elyaf yüzeylerine uygulanan darbeler neticesinde kompozitte oluşan darbe davranışları oda sıcaklı̆ğında deneysel olarak incelenmiştir. Darbe deneyleri için $220 \mathrm{~mm}$ x $330 \mathrm{~mm}$ boyutlarında farklı oranlarda alümina ve silika katkılı 12 tabakalı kevlarcam elyaf/epoksi hibrit kompozit üretimi yapılmıștır. Kompozitler alümina ve silika oranlarına göre 4 ayrı gruba (A0S0, A0S5, A2S3, A5S0) ayrılarak, herbir numuneye 60J darbe enerjisi uygulanmıştır. Her grup kompozit için numunelerin kevlar ve cam elyaf yüzeylerine 60j'lük darbe enerjisi ile darbe testi uygulanarak farklı yüzeylere uygulanan darbe testlerinin darbe davranışı üzerine etkileri incelenmiştir. Çalışma sonucunda bütün kompozit grupları için; darbe uygulanan üst yüzeyin kevlar olması halinde oluşan maksimum kuvvet değerlerinin, üst yüzeyi cam elyaf olan numunelerin maksimum kuvvet değerlerinden daha yüksek olduğu görülmüștür.
\end{abstract}

\section{Investigation of Effect on Impact Behaviour of Impact Energies Applied on Glass and Kevlar Surfaces of Functionalized Alumina and Silica Additive Kevlar-Glass Fiber/Epoxy Resin Hybrid Composites}

\section{Keywords}

Glass fiber,

Kevlar,

Alumina,

Silica,

Impact behavior,

Hybrid composite

\begin{abstract}
Composite materials can be subjected to various impact types depending on their application. Depending on the impact energy, additive material and its ratio with resin, strike probe and impact surface etc., composite material shows various types of damages. In this study, the impact behavior of kevlar-glass fabric penetrated epoxy resin hybrid composite specimens which contains various ratio of alumina and silica were investigated experimentally at room temperature. For impact tests, 12 layer kevlar-glass fiber/epoxy hybrid composite with $220 \mathrm{~mm}$ x $330 \mathrm{~mm}$ dimensions, alumina and silica added were produced. Rely on additive ratio of silica and alumina, 4 group samples, which is labeled as A0S0, A0S5, A2S3, A5S0, was selected for determining the impact behaviour at different silica and alumina ratio under 60J impact energy. For each group of composites, impact tests were applied to the surfaces of kevlar and glass fiber surfaces with a 60J impact energy impact test on the impact behavior of the samples. At the end of the study, for all composite groups; it was seen that the maximum force values formed when the impacted top surface was kevlar were higher than the maximum strength values of the samples with top surface glass fiber.
\end{abstract}




\section{Giriş}

Kompozitler uygulama alanlarındaki kullanımları sırasında darbelere maruz kalabilirler. Örneğin askeri uçak gövdesine çarpan bir mermi ya da bir arabadaki kompozit yaprak yayın stabilize bir yolda taşa değmesi gibi durumlarda tabakalı kompozitlerin darbelere karşı göstermiş oldukları dirençler büyük önem arz eder. Kompozitlerin darbe dayanımı; malzeme sistemi, tabakalar arası mukavemet, diziliş sırası gibi malzemeye ait faktörlerin yanısıra çarpan cismin hızl, kütlesi, boyutu gibi darbenin yapısına ait faktörlere de bağlıdır. Darbe, tabakalı kompozitin mukavemetini azaltmakla beraber tabakalar arasında da ayrılmaların (delaminasyonların) başlamasına neden olur. Delaminasyon gözle görülemediği için durum daha da sorunlu bir hal alır [1]. Bu nedenle kompozitlerin kullanım yerinde maruz kalabileceği yük ve etkileri karşılayabilecek nitelikte üretilmesi gerekir. Kompozit yapılar üzerine yabancı nesnelerin darbesi neticesinde yapıda iç hasar oluşması çok büyük bir oranda yapının mukavemetini azaltmaktadır. Bu tip darbeleri incelerken olayın dinamiğinin, sebep olunan hasarın büyüklüğünün ve yapının özelliklerinin tahmininin iyi anlaşılması gerekmektedir [2]. $\mathrm{Bu}$ amaçla tabakalı kompozit malzemelerin düşük hızlı darbe davranışları üzerine literatürde birçok çalışmalar yapılmıştır [3-7].

Yüksek mekanik özelliklerinden dolayı kompozit malzemelerin; uzay endüstrisinin yanında, gemi, havacılık, inşaat, makine, spor ve diğer alanlarda da isteğe göre tasarlanabilmesi için sürekli araştırmalar yapılmaktadır. $\mathrm{Bu}$ amaçla günümüzde yüksek mukavemetli ve darbe yüklerine karşı dirençleri yüksek olan hibrit kompozit malzemeler üretilmeye başlanmıştır. İki veya daha fazla farklı fiber takviyesinin aynı matris içinde bulunduğu kompozit malzeme grubu hibrit kompozit olarak adlandırılır. Valença vd. tarafından yapılan bir çalışmada, epoksi reçine matrisli kevlar kompoziti ile epoksi reçine matrisli cam/kevlar hibrit kompozitinin mekanik özellikleri araştırılmış ve epoksi ile güçlendirilmiş cam/kevlar hibrit kompozitlerin çekme mukavemeti, darbe enerjisi ve eğme mukavemetlerinin epoksi reçineli kevlar kompozitlere göre daha yüksek olduğu rapor edilmiştir [8].

Hibrit kompozit malzemelerin düşük hızlı darbe davranışları üzerine deneysel çalışmalar yapılmış ve analitik yöntemler geliştirilmiştir: Rafiq vd., ağırlıkça $\% 0, \% 1,5$ ve $\% 3$ oranında nanokil ilaveli cam elyaf takviyeli epoksi hibrit kompozitlerde nanokil ilavesinin darbe direncini nasıl etkilediğini incelemişlerdir. Kompozit plakalara 10J ila 50J arasında değişen dört farklı darbe enerjisi uygulanmıştır. Nanokil ilaveli hibrit kompozitlerin nanokilsiz kompozitlere kıyasla daha iyi darbe dayanımı sergilediği rapor edilmiştir. Nanokil ilavesinin numunelerin rijitliğini arttırdığı bildirilmiştir. Ağırlıkça \%3 oranında nanokil ilaveli numunelerde maksimum yükteki iyileşmenin \% 14 civarında olduğu rapor edilmiştir. Optimum özelliklerin ise maksimum yükte yaklaşık \% 23 iyileşme ve rijitlikte \% 11 artış ile ağırlıkça \%1,5 oranında nanokil ilaveli hibrit kompozit numunelerde elde edildiği belirtilmiştir. Bunun yanı sıra darbe hasarının artan darbe enerjisi ile büyüdüğü ve hibrit nanokompozitlerde oluşan hasarın nanokilsiz kompozitlere nazaran daha küçük olduğu rapor edilmiştir [9]. Reis vd., kevlar fiber ve dolgu maddeli epoksi matrisli kompozitlerin darbe davranıșını ve hasar toleransını incelemişlerdir. Çalışmada kompozitlerin darbe davranışını iyileştirmek için mantar tozu ve organik olarak modifiye edilmiş nanokil olmak üzere iki farklı dolgu maddesi kullanılmıştır. Kompozitin üretiminde daha homojen bir dağılım elde edilmesi ve matris ile nanokilin ara yüzeye iyi yapışmasının sağlanması amaciyla epoksi reçineye uygun özel bir işlem uygulanmıştır. Çalışma sonucunda ilave edilen dolgu maddelerinin maksimum darbe yükünü arttırdığı fakat deplasmanı azalttığı rapor edilmiştir. Nanokil ilavesi ile daha yüksek maksimum darbe yükleri ve daha düşük deplasmanlar sağlandığı belirtilmiştir [10]. Öner vd., dokuma cam kumaş ve epoksiden oluşan kompozite ağırlıkça değişik oranlarda (\% 0,5, $\%$ 0,75, \% 1 ve \% 1,25 ) karbon nanotüp ilave ederek el yatırma yöntemi ile ASTM standartlarına uygun olarak ürettikleri kompozit numunelerin çekme, eğilme ve termomekanik yükleme etkisi altındaki davranışlarını incelemişlerdir. Karbon nanotüp oranı $\% 0,75$ 'e kadar olan numunelerde çekme ve eğilme dayanımının arttı̆̆ı belirtilmiştir. Dolayısıyla çekme ve eğilme dayanımları açısından en iyi sonuçların ağırlıkça \% 0,5 ve \% 0,75 karbon nanotüp ilaveli numunelerde görüldüğü rapor edilmiştir. Karbon nanotüpün homojen dağılmaması yani topaklanması nedeniyle bazı oranlarda karbon nanotüplü numunelerin çekme ve eğilme dayanımlarının katkısız numunelere oranla azaldığı gözlenmiştir [11]. Mahdi vd., nanopartikül ilavesininin karbon fiber takviyeli plastik kompozitlerin darbe davranışına etkilerini araştırmışlardır. Karbon fiber takviyeli plastik kompozitlerin darbe performanslarını artırmak amacıyla karbon nanotüp ve nanokilin ayrı ayrı dahil edilerek üretilen tabakalı kompozitler ile karbon nanotüp ve nanokilin aynı anda birlikte ilave edilerek üretilen tabakalı hibrit kompozitler karşılaştırılmıştır. Bu amaçla üretimi yapılan kompozitler ayrı ayrı 30J, 40J ve 50J enerji seviyelerinde darbe yüküne maruz bırakılarak nanotüp ve nanokilin birlikte kullanılması halinde darbe özelliklerinin nasıl değiștiği araştırılmıştır. Çalışmanın sonucu olarak karbon nanotüp ve nanokil ilavesinin karbon fiber takviyeli plastik kompozitlerin darbe özelliklerini iyileştirdiği ve hasar alanlarını azalttığı rapor edilmiştir. Bunun yanısıra hibrit nanopartikül ile güçlendirilen kompozitlerin darbe davranışında, nanotüp ve nanokilin ayrı ayrı kullanıldığı kompozitlere nazaran önemli ölçüde iyileşme gözlendiği belirtilmiştir [12]. 
Sayman vd. tarafından, cam/epoksi, karbon/epoksi ve karbon/cam hibrit kompozitlerin sıcak ortam $\left(90^{\circ} \mathrm{C}\right)$, soğuk ortam $\left(-50^{\circ} \mathrm{C}\right)$ ve oda koşullarında tam delinme gerçekleşene kadar ağırlık düşürme darbe test cihazında darbe testleri yapılarak farklı ortam koşullarındaki darbe davranışları incelenmiştir. Enerji seviyesi sabit tutulup sıcaklık düşürüldüğünde matris kırılmalarının yoğunlaștığı, delaminasyon alanlarının ve alt tabakalardaki fiber matris ayrılmalarının büyüdüğü görülmüştür [13].

Hibrit kompozitlerde, kompozit malzemenin darbe davranışını önemli ölçüde etkileyen çok sayıda dizayn parametresi vardır. Bu parametrelerden başlıcaları istifleme dizilimi, kalınlık ve hibrit kompozitlerin geometrisidir. $\mathrm{Bu}$ parametrelerden istifleme diziliminin yani farklı elyaf kumaşların hibrit kompozitlerin darbe davranıșının belirlenmesinde önemli rolü olduğu bilinmektedir. Park ve Jang tarafından yapılan çalışmada, ince tabakalı kompozitlerin darbe davranışı üzerine istifleme diziliminin etkisini araștırmak amacıyla aramid fiber/cam fiber takviyeli hibrit kompozitler üretilmiştir. Hibrit kompozitlerin darbe özellikleri üzerine aramid tabakanın tabakalı kompozitteki pozisyonunun etkisi araştırılmıştır. Aramid tabaka darbe uygulanan yüzeyde olduğu zaman kompozitin daha yüksek bir darbe enerjisi sergilediği rapor edilmiştir. Aramid elyaf ve cam elyaf takviyeli kompozitlerin kalınlık değișimine göre farklı darbe davranışı gösterdikleri belirtilmiștir. Darbe davranışındaki bu farklılığın tabakalar arasındaki arayüzeyde meydana gelen absorbe edilen enerjinin elyaflara göre farklılı göstermesinden kaynaklı olacağ belirtilmiștir [14]. Park ve Jang tarafından yapılan bașka bir çalışmada ise üç tabakalı aramid fiber/cam fiber hibrit kompozitlerin, tabaka dizilim sırasının ve yüzey davranışının düşük hızlı darbe sonrası bası performansı ve darbe sonrası artık bası mukavemetleri incelenmiştir. Darbe enerjisi arttıkça kompozitlerin artık mukavemetinin, delaminasyon alanının artmasından dolayı düştüğü rapor edilmiştir. Sonuç olarak, bası yükü altında aramid fiberli yüzeyin delaminasyon alanının ve delaminasyon başlama direncinin arttığı bildirilmiştir [15].

Bu çalışmada, düşük hızlı darbe deneyleri için farklı katkı oranlarında alümina ve silika katkılı kevlar elyaf ve cam elyaf kumaş takviyeli epoksi reçineli tabakalı hibrit kompozit malzemeler üretilmiștir. Tabakalı hibrit kompozitlerin tasarımı, 3 tabaka kevlar, 1 tabaka cam elyaf kumașın ardıșık olarak üst üste sıralanmasıyla 12 tabakalı olacak șekilde yapılmıștır. Bu şekilde kompozitin bir yüzeyi kevlar diğer yüzeyi cam elyafdan oluşmuştur. Üretimi yapılan 4 farklı konfigürasyona sahip kompozitler için kevlar (aramid) ve cam elyaf yüzeylerine ayrı ayrı 60J darbe enerjisi uygulanarak fonksiyonellendirilmiş alümina ve silika katkıl hibrit kompozitlerin farklı yüzeylerine uygulanan darbe enerjisinin kompozitin darbe davranışları üzerine etkileri araştırılmıştır.

\section{Materyal ve Metot}

\subsection{Hibrit Kompozitlerin Üretimi}

Deneysel çalışma için öncelikle Süleyman Demirel Üniversitesi Makine Mühendisliği Laboratuarında farklı oranlarda alümina ve silika içeren kevlar ve cam elyaf takviyeli epoksi reçineli 12 tabakalı hibrit kompozit plakalar üretilmiştir. Kompozitin üretiminde fiber malzeme olarak $300 \mathrm{gr} / \mathrm{m}^{3}$ yoğunluğa sahip tek yönlü cam kumaş ve $207 \mathrm{gr} / \mathrm{m}^{3}$ yoğunluğunda kevlar kumaş kullanılmıştır. Katkı maddesi olarak \% 99,90 saflık ve $1 \mu$ boyutunda alümina ve $\% 99,85$ saflık ve $1 \mu$ boyutunda silika kullanılmıştır. Reçine malzemesi olarak da BRTR Kimya marka BREPR101 epoksi ve sertleștirici kullanılmıştır. 100 gr epoksiye 60gr sertleștirici karıștırılarak reçine sistemi oluşturulmuştur. Ağırlıkça farklı konsantrasyonlarda alümina $\left(\mathrm{Al}_{2} \mathrm{O}_{3}\right)$ ve silika $\left(\mathrm{SiO}_{2}\right)$ takviye edilerek hazırlanan epoksi reçine-sertleştirici karışımın homojen olarak karışması için mekanik karıştırıcı kullanılmıştır. Daha sonra el yatırma yöntemi ile elyaf kumaşların üzerlerine epoksi-sertleştirici karıșımından oluşan reçine sistemi sürülerek kompozitlerin üretimi gerçekleştirilmiştir [16]. Kompozit plakalar, katmanlar arasındaki hava boşluklarının giderilmesi amaciyla 12 saat vakumlamaya tabi tutulmuştur. Şekil 1'de görülen alümina ve silika katkı maddeleri kullanılarak 4 farklı konsantrasyonda hibrit kompozit plaka üretilmiştir (Şekil 1). Tabakalı hibrit kompozitlerin tasarımı, 3 tabaka kevlar, 1 tabaka cam elyaf kumaşın ardıșık olarak üst üste sıralanmasıyla 12 tabakalı olacak şekilde yapılmıştır.
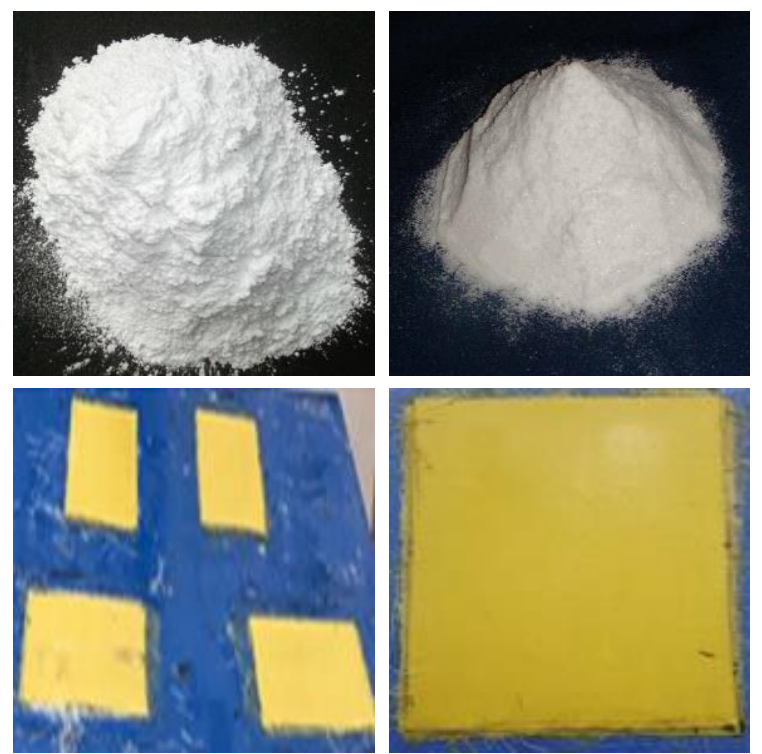

Şekil 1. Üretimi yapılan alümina ve silika katkılı hibrit kompozit plakalar.

Düşük hızlı darbe deneyi uygulanmak üzere $220 \mathrm{mmx} 330 \mathrm{~mm}$ boyutunda üretilen bu 12 tabakalı hibrit kompozit plakalardan LNC-M520H su jeti yardımıla $100 \mathrm{mmx} 100 \mathrm{~mm}$ boyutunda deney numuneleri kesilmiştir (Şekil 2). 


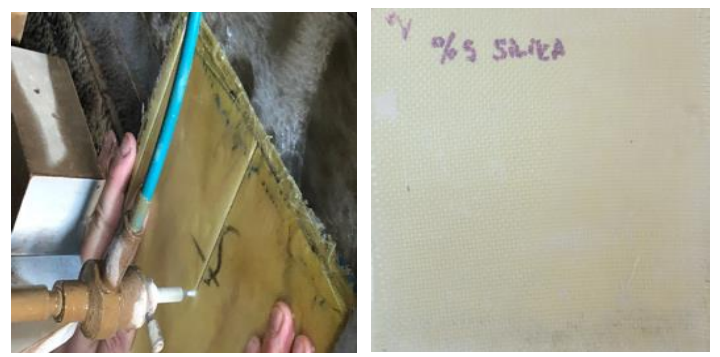

Şekil 2. Hibrit kompozitlerin kesimi ve deney numunesi.

Üretimi yapılan kompozit malzemeler içerdiği katkı maddeleri oranlarına göre 4 ayrı gruba ayrılmıștır. 12 tabakalı olarak tasarlanan fonksiyonellendirilmiş alümina ve silika katkılı hibrit kompozit numunelerin alümina ve silika katkı oranları ve ortalama tabaka kalınlıkları Tablo 1'de verilmiştir.

Tablo 1.Hibrit kompozit numunelerinin gruplandırılması

\begin{tabular}{|c|c|c|c|}
\hline $\begin{array}{c}\text { Grup } \\
\text { No }\end{array}$ & $\begin{array}{c}\text { Katkı Oranı } \\
(\%)\end{array}$ & Adlandırma & $\begin{array}{c}\text { Ortalama } \\
\text { Tabaka } \\
\text { Kalınlığ } \\
\text { (mm) }\end{array}$ \\
\hline 1 & $\begin{array}{c}\text { \%0 Alumina } \\
\text { \%0Silika }\end{array}$ & A0S0 & 3,72 \\
\hline 2 & $\begin{array}{c}\text { \%0 Alümina } \\
\text { \%5Silika }\end{array}$ & A0S5 & 3,72 \\
\hline 3 & $\begin{array}{c}\text { \%2 Alümina } \\
\text { \%3Silika }\end{array}$ & A2S3 & 3,72 \\
\hline 4 & $\begin{array}{c}\text { \%5 Alümina } \\
\text { \%0Silika }\end{array}$ & A5S0 & 3,72 \\
\hline
\end{tabular}

\section{A: Alümina, S: Silika}

Tablo 1'den görüldüğü üzere; 1 . grup A0S0 kompozitleri alümina ve silika içermemekte olup kontrol grubu olarak üretilmişlerdir. 2. grup A0S5 sadece silika, 4 grup A5S0 sadece alümina katkılı olarak üretilmiștir. 3. grup A2S3 konfigürasyonu ise hem alümina hem de silika içermektedir.

\subsection{Hibrit Kompozitlerin Darbe Testleri}

Hibrit kompozit numunelerin düşük hızlı darbe testleri Süleyman Demirel Üniversitesi Yenilikçi Teknolojiler Uygulama ve Araştırma Merkezi'nde bulunan CEAST Fractovis Plus ağırlık düşürme test cihazında yapılmıștır (Şekil 3).

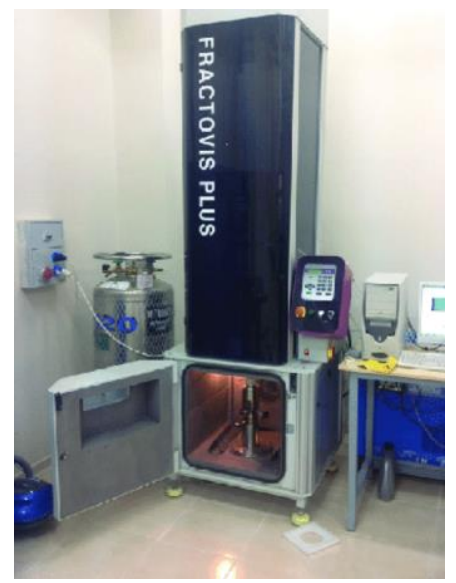

Şekil 3.Fractovis Plus darbe test cihazı.
Düşük hızlı darbe testleri oda sıcaklığında yapılmıștır. Testler sırasında kullanılan vurucu kütlesi 4.926 kilogramdır. Cihaz içerisindeki pnömatik bir düzenek yardımıyla numunelerin ankastre sınır şartlarında darbe deneylerinin yapılması sağlanmıştır. Numuneler 60J'lük darbe enerji seviyesinde darbe yüküne maruz bırakılmıștır. Visual Impact adlı bir yazılımla donatılan cihaz, zamana bağlı olarak vurucu ile numune arasinda meydana gelen temas kuvvetini, vurucunun hızını ve numunenin çökme miktarlarını vermektedir. Darbe enerjisine göre vurucunun numunelere ilk çarpma hızı 4,85 m/s'dir. Hibrit kompozitlerin darbe deneylerinde Şekil 4'te verilen ucu yarım küre şekline sahip 10 mm'lik vurucu uç kullanılmıştır.

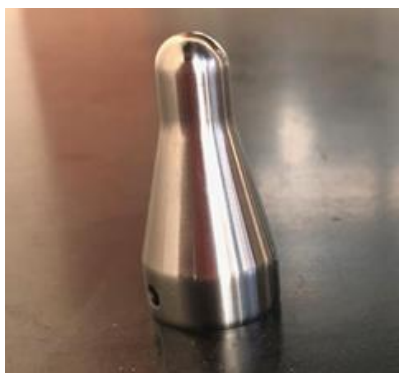

Şekil 4. Darbe deneyinde kullanılan vurucu uç.

Darbe deneyleri sonucunda elde edilen veriler kullanılarak çizilen kuvvet - yerdeğiştirme eğrilerine bakılarak darbe uygulanan numunede oluşan hasar modları hakkında fikir edinmek mümkündür. Darbe testleri sonucunda genellikle geri sekme (kapalı eğri), nüfuziyet (saplanma) ve delinme (açık eğri) olmak üzere üç hasar modu olușur (Șekil 5).

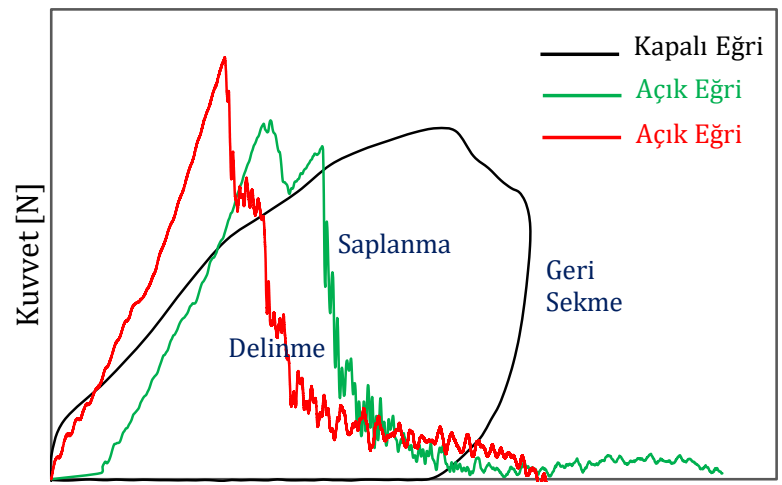

Deplasman (mm)

Şekil 5.Kuvvet - yer değiștirme eğrileri.

Düşük enerjili darbe deneyi sonucunda elde edilen veriler kullanılarak çizilen kuvvet-yerdeğiștirme eğrilerinin parabolik bir eğri șekline sahip olduğu görülmektedir (Şekil 5). Uygulanan darbe enerjisinin artmasiyla meydana gelen kuvvet de artmakta, saplanma ve delinme eğrilerinde görüldüğü üzere maksimum kuvvet değeri hemen hemen sabit bir değer olmaktadır. Numunede delinme meydana geldiğinde kuvvetin sıfır olması gerekir fakat vurucu ve numune arasındaki sürtünme nedeniyle eğrinin uç kısmı yatay eksene paralel şekilde ilerler. 
Şekil 5'den görüldüğü üzere artan darbe enerjisi altında oluşan eğriler kapalı tip ve açık tip eğri olmak üzere iki kısma ayrılır. Kapalı tip eğri vurucunun numuneye temas etmesinden sonra vurucunun numune yüzeyinden geri sekmesiyle oluşan eğrilerdir. Yani uygulanan darbe enerjisinin büyük bir kısmı numune tarafından absorbe edilmiş, absorbe edilmeyen enerji de vurucunun geri sekmesi için kullanılmıştır. Eğer bir eğri açık tip ise vurucu numuneye ya saplanmıştır ya da numune delinmiştir. Buna göre numuneye saplanan vurucu numune kalınlığı boyunca aşağı doğru hareket eder ve artık numune yüzeyinden geri sekme meydana gelmez. Darbe enerjisi daha da arttırıldığında vurucu numuneye saplanır, numune kalınlığı boyunca hareket eder ve sonunda da numuneyi delerek alt yüzeyden çıkar yani delinme olayı gerçekleşmiş olur $[16,17]$.

\section{Bulgular}

Darbe uygulanan yüzeydeki elyafın darbe dayanımına etkisinin araştırılması amacıyla üretilen hibrit kompozitler, 3 tabaka kevlar, 1 tabaka cam elyaf olacak şekilde ardışık olarak üst üste sıralanarak 12 tabaka olarak tasarlandığından kompozit numunelerin bir yüzeyi kevlar diğer yüzeyi cam elyaftan oluşmaktadır. Tablo 1'de verilen 4 grup hibrit konfigürasyonlarının her biri için numunelerin hem üst (kevlar elyaf) ve hem de alt (cam elyaf)

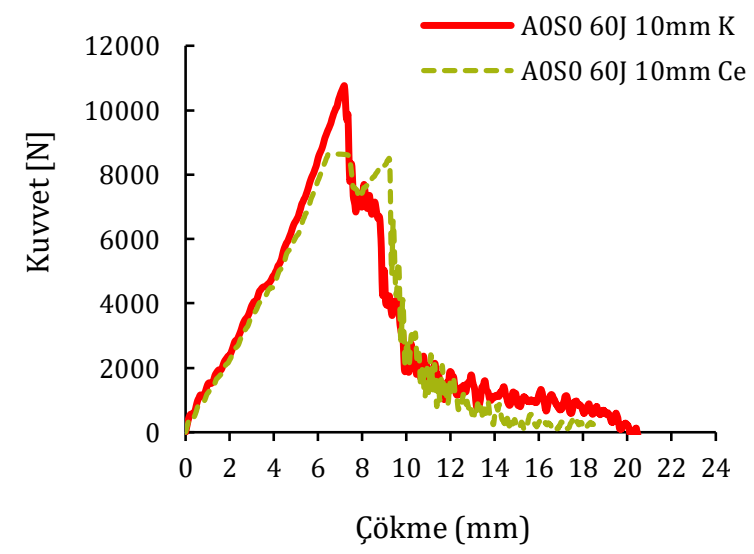

a) 1.grup (A0S0) numuneler için kuvvet - çökme eğrileri

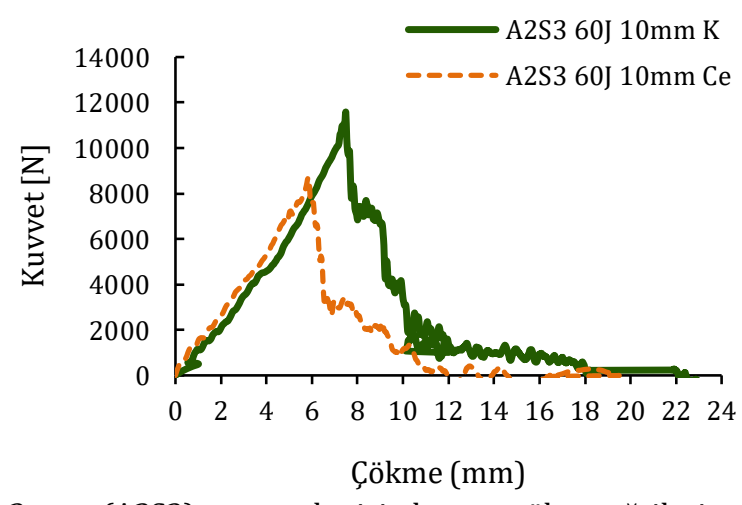

c) 3.grup (A2S3) numuneler için kuvvet-çökme eğrileri yüzeylerine ayrı ayrı 60J darbe enerjisi uygulanarak farklı (kevlar ve cam) yüzeylerin hibrit kompozitin darbe davranışını nasıl etkilediği araştırılmıştır. Bu doğrultuda 60J darbe enerjisi uygulandıktan sonra elde edilen veriler doğrultusunda her bir hibrit kompozit konfigürasyonu için kuvvet-çökme eğrileri çizilmiştir (Şekil 6).

Grafiklerdeki "K" gösterimi kevlar'ı, "Ce" gösterimi ise cam elyafı ifade etmektedir. Şekil 6'da verilen kuvvet-çökme eğrilerinden, 60J darbe enerji değeri için tüm konfigürasyonlara ait kompozit numunelerinin darbe deneyleri sonucunda benzer darbe davranışı gösterdikleri görülmektedir. Grafiklerden her 4 konfigürasyon için de hem kevlar hem de cam elyaf yüzeyde açık tip eğri oluştuğu görülmektedir. Dolayısıyla tüm konfigürasyonlar için 60J darbe enerjisi altında kompozit numunelerde delinme meydana gelmiştir. Şekil 6'da verilen grafikler yardımıyla kevlar ve cam yüzeyler karşılaştırılacak olursa, tüm konfigürasyonlarda kevlar yüzeyin, cam elyaf yüzeye göre daha fazla maksimum kuvvet taşıdığı görülmektedir. Ayrıca kevlar (aramid) elyafın cam elyafa göre daha fazla enerji absorbe ettiği görülmektedir. Kevlar ve cam elyafın hibrit kompozitin darbe dayanımına etkisinin daha iyi anlaşılabilmesi adına tüm konfigürasyonlar için kevlar ve cam elyaf yüzeylerde oluşan maksimum kuvvet değerleri Şekil 7'de sütun grafik olarak verilmiştir.

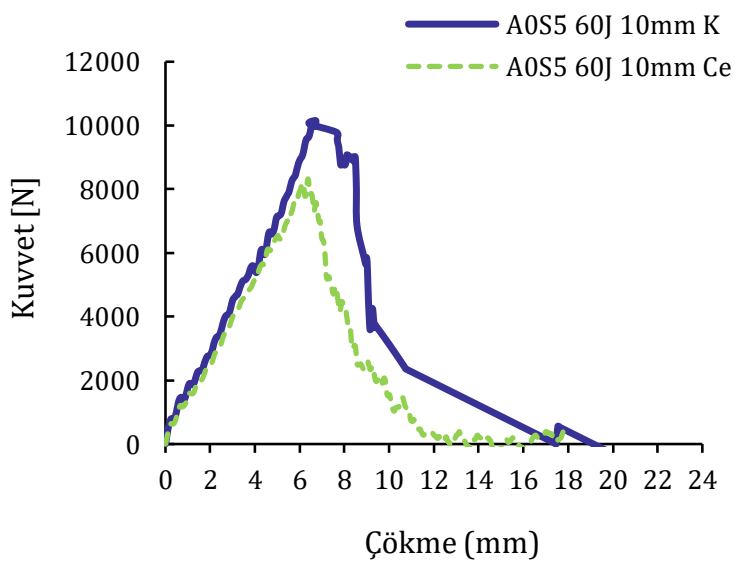

b) 2.grup (A0S5) numuneler için kuvvet - çökme eğrileri

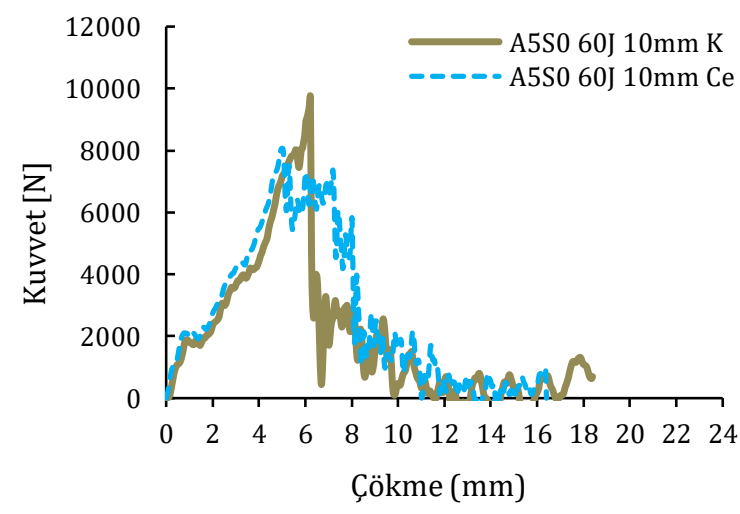

d) 4.grup (A5S0) numuneler için kuvvet-çökme eğrileri

Şekil 6. 60J darbe enerjisi uygulanan 4.grup hibrit konfigürasyon numuneler için kuvvet - çökme (F-d) eğrileri. 


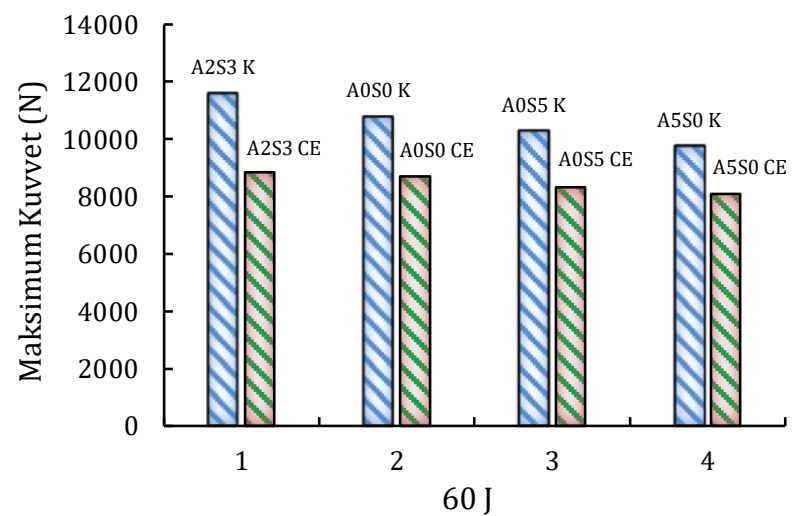

Şekil 7.Tüm gruplar için maksimum kuvvet-darbe enerjisi grafiği.

Şekil 7'den hem kevlar hem de cam elyaf yüzeyler için en yüksek maksimum kuvvet değerlerinin hem alümina hem de silika içeren 3. grup A2S3 konfigürasyonunda meydana geldiği görülmektedir. Grafik alümina ve silika katkıları açısından değerlendirildiğinde; hem alümina hem de silika içeren 3. grup A2S3 konfigürasyonunun maksimum kuvvet değerlerinin, kontrol grubu olan katkısız A0S0 konfigürasyonunun maksimum kuvvet değerlerinden daha yüksek olduğu görülürken, sadece alümina ve sadece silika içeren A0S5 ve A5S0 konfigürasyonlarının maksimum kuvvet değerlerinin kontrol grubu olan A0S0 konfigürasyonundan daha düşük olduğu görülmektedir. Bu sonuç literatür ile de örtüşmektedir. Mahdi vd. tarafından yapılan çalışmada da benzer şekilde nanotüp ve nanokilin birlikte kullanıldığı hibrit kompozitlerin darbe davranışlarının, nanotüp ve nanokilin ayrı ayrı kullanıldığı kompozitlerin darbe davranışlarına nazaran daha iyi olduğu rapor edilmiştir [12].

Şekil 7'de verilen grafik ıșığında kevlar ve cam yüzeylerin darbe dayanımları karşılaştırılacak olursa; tüm konfigürasyonlar için kevlar yüzeyde oluşan maksimum kuvvet değerlerinin cam yüzeyde oluşan maksimum kuvvet değerlerinden daha yüksek olduğu görülmektedir. Kevlar yüzeyde oluşan maksimum kuvvet değerlerinin cam elyaf yüzeylerde oluşan maksimum kuvvet değerlerine göre artışı; A2S3 kompoziti için \%30,97, A0S0 için \%23,99, A0S5 için $\% 23,18$, A5S0 için \%20,14'tür. Buradan hareketle; kevlar yüzeye darbe uygulanan kompozit numunelerin yük taşıma kapasitelerinin, cam elyaf yüzeye darbe uygulanan kompozit numunelere göre daha yüksek olduğu sonucuna varılmıştır. Bu sonuç literatür ile de uyum içindedir. Park ve Jang tarafından yapılan çalışmada, ince tabakaların darbe davranışı üzerine tabaka dizilim sırasının etkisini araştırmak amacıyla aramid fiber/cam fiber hibrit kompozitler üretilmiștir. Aramid tabakaya darbe uygulandığında kompozit daha yüksek bir darbe enerjisi göstermiştir. Bunun darbeye maruz ince tabaka yüzeylerinde daha yüksek deformasyon meydana gelmesi ve tabaka ara yüzeylerinde farklı enerji absorbe edilmesinden kaynaklı olacağı belirtilmiştir [14].

Şekil 8'de tüm hibrit kompozit konfigürasyonların kevlar ve cam elyaf yüzeylerinde oluşan maksimum çökme değerleri grafik olarak verilmiştir.

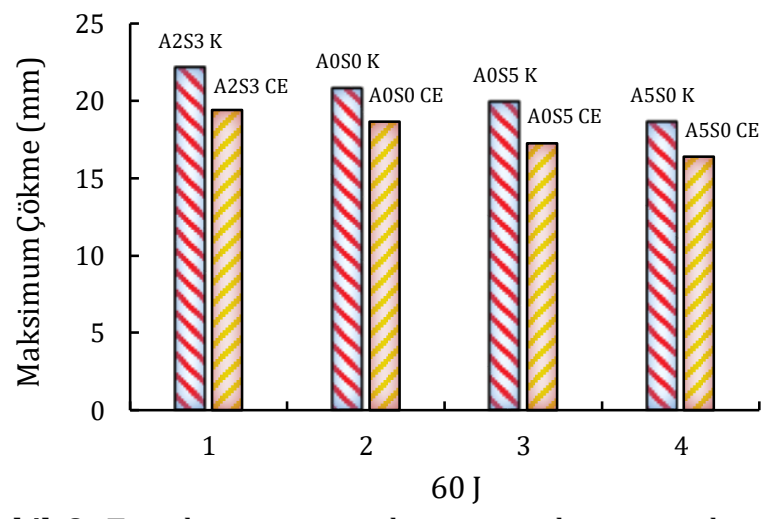

Şekil 8. Tüm kompozit grupları için maksimum çökmedarbe enerjisi grafiği.

Şekil 8'den hem kevlar hem de cam elyaf yüzeyler için en yüksek maksimum çökme değerlerinin hem alümina hem de silika içeren 3. grup A2S3 konfigürasyonunda meydana geldiği ve çökme miktarları açısından grup sıralamasının A2S3 > A0S0 > A0S5 > A5S0 şeklinde olduğu görülmektedir.

Bir absorbe edilen enerji-zaman grafiği numune yüzeyinden geri sekme (rebounding), vurucu ucunun numuneye saplanması (penetration) ve vurucunun numuneyi delip geçmesi (perforation) gibi üç özel duruma ait eğrileri gösterir. Absorbe edilen enerji, kuvvet-çökme (F-d) eğrisinin altında kalan alandan hesaplanmaktadır. Absorbe edilen enerji - zaman eğrilerinde vurucunun numune yüzeyinden geri sekmesi durumunda vurucunun sahip olduğu enerjinin tamamı numune tarafından absorbe edilemez. $\mathrm{Bu}$ durumda absorbe edilemeyen darbe enerjisi vurucunun numune yüzeyinden geri sekmesi için harcanır. Vurucunun numuneye saplanması durumunda vurucunun sahip olduğu darbe enerjisinin tamamı numune tarafından absorbe edilir. Vurucunun numuneyi delip geçmesi durumunda ise vurucu ile numune arasındaki sürtünme eğrisinin altında kalan alanın da darbe cihazının programı tarafindan hesaplanan absorbe edilen enerji miktarına katılmasından dolayı eğri yukarı doğru yönlenir [16, 17]. Şekil 9'da 60J darbe enerjisi uygulanan A0S0, A0S5, A2S3, A5S0 hibrit kompozit konfigürasyonlarına ait absorbe edilen enerji-zaman eğrileri verilmiştir. Absorbe edilen enerji-zaman eğrileri incelendiğinde, tüm konfigürasyonlar için eğrinin yukarı doğru yönlendiği görülmektedir. Buradan hareketle numunelerde delinme meydana geldiği anlaşılmaktadır. 

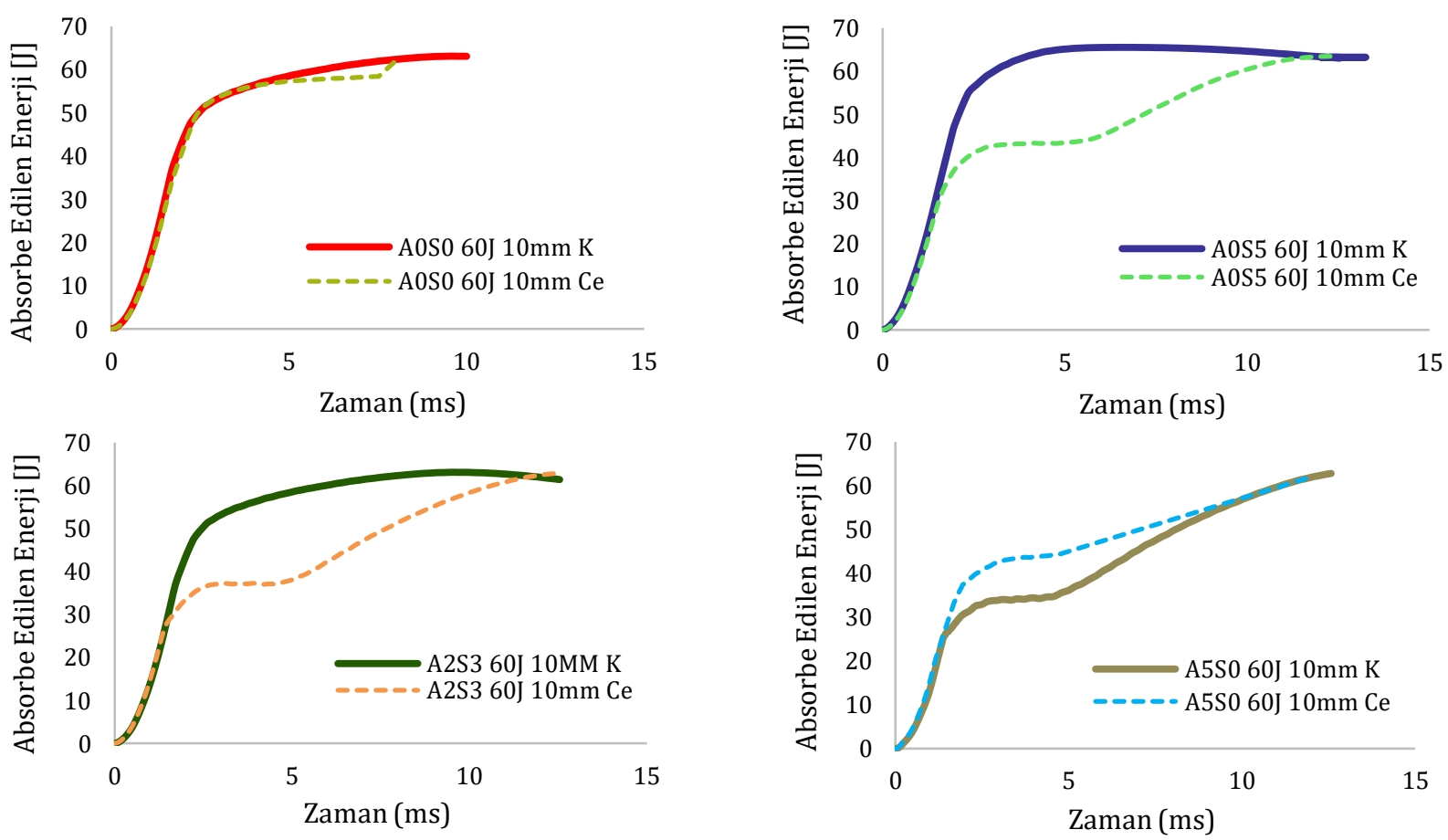

Şekil 9. Tüm hibrit kompozit konfigürasyonlarına ait absorbe edilen enerji-zaman eğrileri.
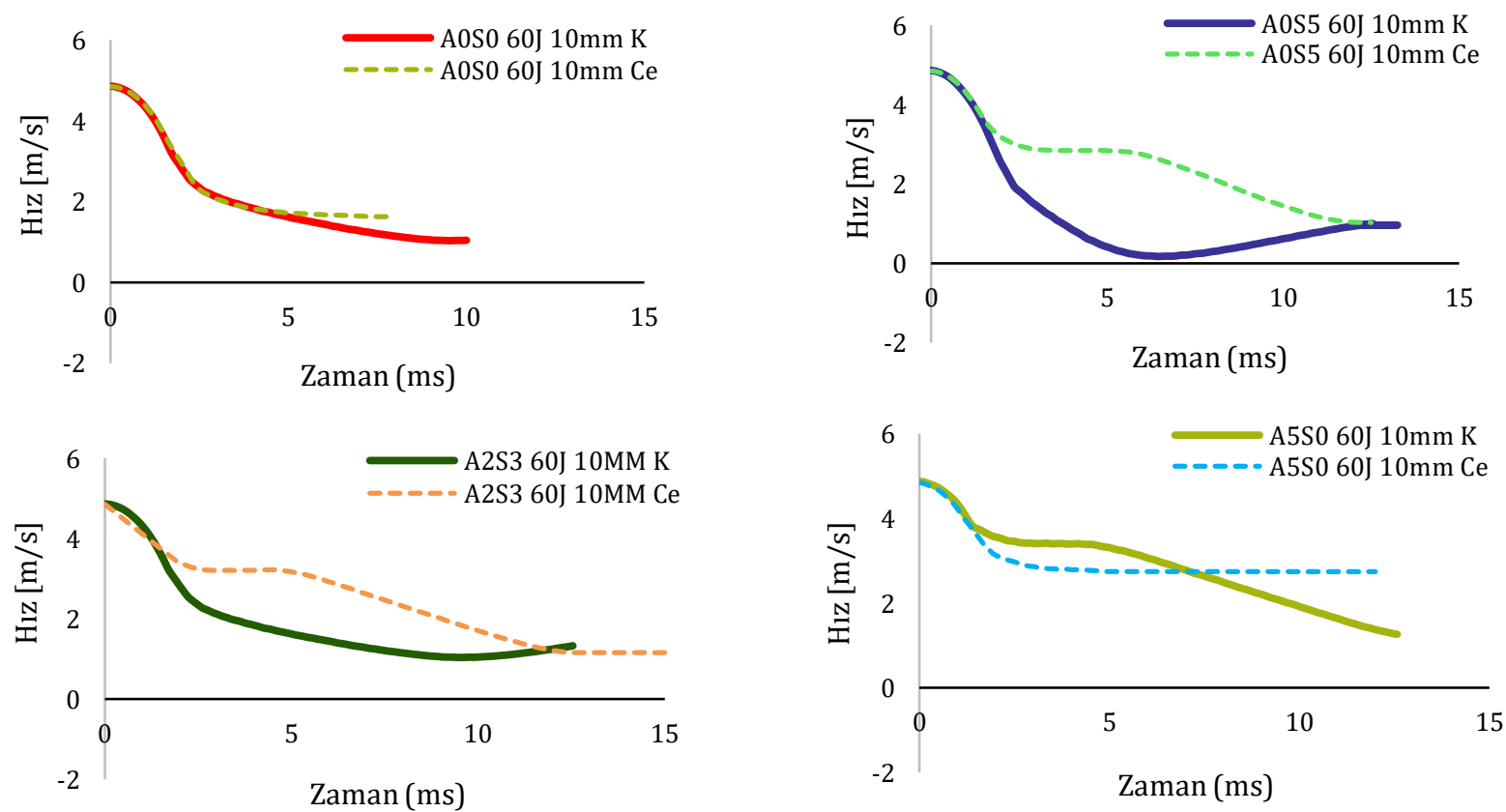

Şekil 10. Tüm hibrit kompozit konfigürasyonları için hız-zaman eğrileri.

Şekil 10'da 60J darbe enerji değeri için tüm hibrit kompozit konfigürasyonlarına ait hız-zaman eğrileri verilmiştir. Şekilde verilen hız-zaman eğrilerinden, tüm konfigürasyonların benzer darbe davranışı gösterdikleri görülmektedir. Tüm konfigürasyonlar için kevlar elyaf ve cam elyaf yüzeylere uygulanan darbe deneyleri sonucunda numunelerin tamaminda delinme hasar modu oluştuğu için hız-zaman eğrilerinin tamamının pozitif tarafta olduğu dolayısıyla vurucunun her bir konfigürasyon için pozitif bir hıza sahip olduğu görülmektedir.

Tüm bu grafikler ışığında kevların cam elyafa göre darbe dayanımının daha iyi olduğu sonucuna ulaşılmıştır. $\mathrm{Bu}$ sonuç literatür tarafından da desteklenmektedir: Park ve Jang tarafindan yapılan çalışmada, sadece cam elyaf ve sadece kevlar elyafdan oluşan bir tabakalı kompozitler darbe deneyine maruz bırakıldığında kevlar elyafdan oluşan tabakalı kompozitte $1915 \mathrm{~N}$ maksimum yük oluşurken, cam elyafdan oluşan bir tabakalı kompozitte 1261N maksimum yük oluştuğu rapor edilmiştir. Buradan hareketle tek tabakalı kompozitte kevlar elyafın cam elyafa göre daha fazla maksimum yük taşıdığı belirtilmiştir. Bunun yanı sıra cam elyafdan oluşan bir tabakalı kompozitte 3,12J toplam darbe enerjisi oluşurken kevlar elyafdan oluşan bir tabakalı kompozitte oluşan toplam darbe enerjisinin 14,33J 
olduğu rapor edilmiştir. Benzer şekilde 3 tabakalı hibrit konfigürasyonlar oluşturarak darbe uygulanan üst yüzeydeki elyaf tabakada oluşan maksimum yükleri araştırmışlardır. CAA (cam/aramid/aramid) şeklinde tasarlanan 3 tabakalı hibrit kompozitin cam yüzeyine darbe uygulandığında $3561 \mathrm{~N}$ maksimum yük ve 10,54J toplam darbe enerjisi oluştuğu bildirilirken, AAC (aramid/aramid/cam) şeklinde tasarlanan 3 tabakalı hibrit kompozitin aramid yüzeyine darbe uygulanması halinde ise $4469 \mathrm{~N}$ maksimum yük ve 13,6J toplam darbe enerjisi oluştuğu rapor edilmiştir [14]. Dolayısıyla hibrit kompozitte kevlar elyafın cam elyafa göre daha fazla maksimum yük taşıdığı ve darbe dayanımının çok iyi olduğu sonucu literatür tarafından da doğrulanmaktadır.

Tabakalı kompozitlerde üst yüzeye darbe uygulanması sonucu öncelikle matriste hasar oluşur. Matristeki hasar çatlak oluşumu ile başlar ve bu çatlak ilerleyerek matris kırılmalarına neden olur. Matrisin așırı zorlanması sonucu gerilmeler fiberlere aktarılır ve fiberler zorlanmaya başlar. Ayrıca matris kırılmaları delaminasyonun başlamasında da etken rol oynar. Üst katmanlardaki çatlak ve kırıklar ara yüzeye ulaştı̆̆ında diğer katman tarafindan durdurulur ve katmanlar arasında delaminasyon olarak ilerlemeye başlar. $\mathrm{Bu}$ şekilde hasar alt tabakalara kadar ulaşır [18]. Şekil 11'de kevlar yüzeye darbe uygulanması halinde darbe sonrası A2S3 kompozit numunesinin üst ve alt yüzeylerinde oluşan hasar bölgesi fotoğrafları verilmiștir.
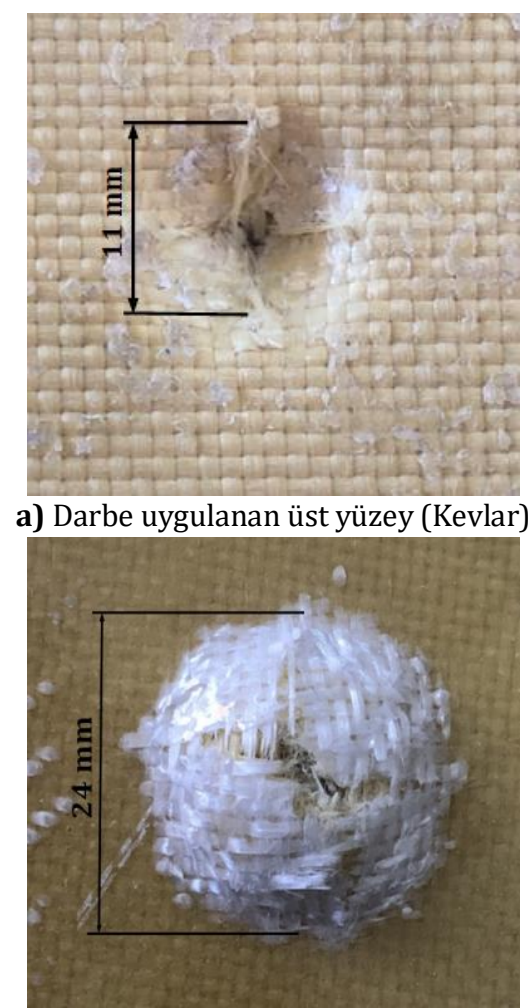

b) Alt yüzey (Cam)

Şekil 11. Kevlar yüzeye darbe uygulanan A2S3 numunesinin üst ve alt yüzey hasar fotoğrafları.
Şekil 11a'dan, kevlar yüzeye darbe uygulanması halinde kompozitin üst yüzeyinde bası gerilmelerinin etkisiyle matris malzemesinde ezilme ile birlikte çatlakların oluştuğu ve bir miktar çökmenin gerçekleştiği görülmektedir. Numune yüzeyine darbe uygulanması sonucu fiberlerin konkav şekil almaya zorlanması ile fiberler uzamaya çalışır. Buna bağlı olarak da fiber kırılmaları oluşur. Üst yüzeydeki katmanlarda darbe sonucu meydana gelen bası ve kesme gerilmeleri sonucu matriste oluşan bu çatlak ve kırılmalar kompozitin iç bölgelerinde delaminasyonlara sebebiyet verir. Kompozitin iç bölgelerinde olușan düșey eğilme kırıklarının büyümesi sonucu zorlanmayan en alt ara yüzeyde de delaminasyon başlar. Alt yüzeydeki katmanlarda meydana gelen eğilme gerilmeleri sonucu ise, eğilmeye bağlı olarak fiber-matris ara yüzey bağı kopar, matriste ve fiberde kırılmalar oluşur. Şekil $11 \mathrm{~b}$ 'den görüldüğü üzere, en alt yüzeyde eğilmeden kaynaklanan çekme gerilmelerinin en fazla olması ve bu yüzeydeki liflerin en fazla çekme uzamasına maruz kalmasından dolayı fiber ve matris malzemesinde kırılmalar artmış ve delinme hasarı meydana gelmiştir.
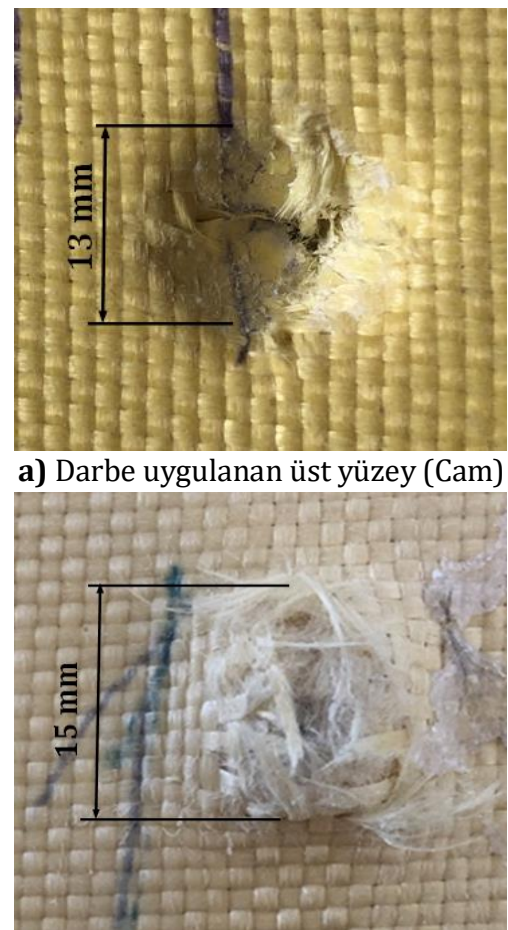

b) Alt yüzey (Kevlar)

Șekil 12. Cam elyaf yüzeye darbe uygulanan A2S3 numunesinin üst ve alt yüzey hasar fotoğrafları.

Şekil 12'de ise A2S3 hibrit kompozitinde cam yüzeye darbe uygulanması halinde darbe sonrası numunenin üst ve alt yüzeylerinde meydana gelen hasar bölgelerinin fotoğrafları verilmiștir. Şekil 12'den, cam yüzeye darbe uygulanması A2S3 numunesinin, kevlar yüzeye darbe uygulanan A2S3 numunesine (Şekil 11) benzer hasar davranışı sergilediği ve numunenin alt yüzeyinde aynı şekilde delinme hasar modunun oluştuğu görülmektedir. Alt yüzeyin kevlar olması 
halinde delinme hasar bölgesinin daha küçük bir alana sahip olduğu gözlenmiștir (Șekil 12b).

Şekil 11 ve Şekil 12 karşılaştırıldığında; kevlar yüzeye darbe uygulanması halinde alt yüzeyde (cam elyafda) oluşan hasar bölgesinin (Şekil 11b), cam yüzeye darbe uygulanması halinde alt yüzeyde (kevlar elyafda) oluşan hasar bölgesinden (Şekil 12b) daha büyük olduğu görülmektedir. Kevlar yüzeye darbe uygulandığında üst yüzeyde oluşan hasar çapı $11 \mathrm{~mm}$ olarak ölçülürken (Șekil 11a), cam yüzeye darbe uygulandığında üst yüzeyde oluşan hasar çapı $13 \mathrm{~mm}$ olarak ölçülmüştür. (Şekil 12a). Bununla beraber kevlar yüzeye darbe uygulanması sonucunda alt yüzeyde (cam elyafda) hasar boyutu $24 \mathrm{~mm}$ olarak ölçülürken (Şekil 11b), cam elyaf yüzeye darbe uygulanması sonucu alt yüzeyde (kevlar elyafda) hasar boyutu $15 \mathrm{~mm}$ olarak (Şekil 12b) ölçülmüştür. Dolayısıyla kevlar yüzeye darbe uygulanması sonucu alt yüzeyde (cam elyafda) oluşan hasar alanının, cam yüzeye darbe uygulanması sonucu alt yüzeyde (kevlar elyafda) oluşan hasar alanına göre daha büyük olduğu gözlemlenmiștir. Elde edilen bu hasar davranışı literatürdeki çalışmalar ışığında, üst tabakanın kevlar (aramid) olması durumunda; aramid elyafın sünek yapısı nedeniyle kompozitin iç bölgelerinde oluşan delaminasyon alanının genişlediği ve bu geniş delaminasyonların kompozitin iç bölgelerinde oluşan hasar alanının da genişlemesine neden olacağından alt tabakadaki hasar alanının da haliyle büyük olacağı șeklinde yorumlanmıştır. Kevlar yüzeye darbe uygulanması durumunda alt yüzeyde oluşan hasar alanının (Şekil $11 \mathrm{~b}$ ), cam yüzeye darbe uygulanması durumunda alt yüzeyde oluşan hasar alanına (Şekil 12b) göre daha büyük olduğu sonucunu literatür de doğrulamaktadır. Park ve Jang tarafından yapılan çalışmada [14], tabakalı kompozitlerin darbe davranışı üzerine tabaka dizilim sırasının etkisini araştırmak amacıyla tasarlanan 3 tabakalı AAC (aramid/aramid/cam) ve CAA (cam/aramid/aramid) hibrit kompozitlerinde darbe uygulanan yüzeyin aramid ve cam elyaf olması halinde kompozitte oluşan darbe hasarının şematik resmi Şekil 13'te verilmiştir

Şekil 13 incelendiğinde, aramid yüzeye darbe uygulanması halinde hem darbenin uygulandığı üst tabakada hem de iç tabakalarda daha büyük bir hasar alanı (Şekil 13a) oluştuğu gözlenirken, cam yüzeye darbe uygulanması halinde tabakalı kompozitin üst ve iç tabakalarında daha küçük bir hasar alanının (Şekil 13b) oluştuğu görülmektedir. Aramid elyaf / cam elyaf hibrit kompozitlerin darbe enerjisinin çoğunlukla laminalar arasındaki arayüzde delaminasyon yoluyla absorbe edildiği belirtilmiştir. Bunun sonucu olarak aramid elyafın cam elyafa göre daha fazla darbe enerjisi absorbe etmesinin bu delaminasyon alanının kapsamı ile ilgili olduğu rapor edilmiştir.

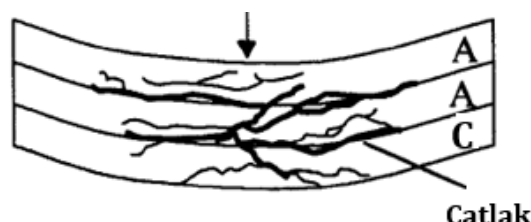

a) 3 tabakalı AAC (aramid/aramid/cam) kompoziti

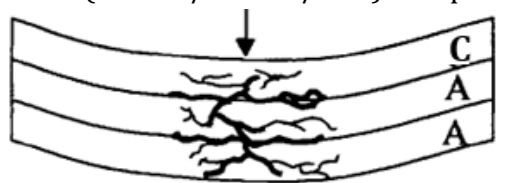

b) 3 tabakalı CAA (cam/aramid/aramid) kompoziti

Şekil 13. İnce tabakalı bir kompozitte oluşan darbe hasarının şematik diyagramı [14].

Şekil 11 ve Şekil 12 birlikte değerlendirilip; üst ve alt yüzeylerde oluşan hasar bölgeleri karşılaştırılacak olursa; hem kevlar elyaf için hem de cam elyaf için alt yüzeydeki hasar bölgesinin üst yüzeye göre daha büyük olduğu görülür. Kevlar yüzeye darbe uygulanması halinde alt yüzeyde (cam elyafta) oluşan hasar bölgesinin üst yüzeye göre çok daha büyük olduğu gözlenmiştir. Diğer konfigürasyonlarda da A2S3 konfigürasyonunda olduğu gibi darbe uygulanmayan alt yüzeydeki deformasyon alanının, darbe uygulanan üst yüzeydeki deformasyon alanına göre daha büyük olduğu görülmüştür. $\mathrm{Bu}$ sonuç literatür ile örtüşmektedir. Lou vd. yapmış oldukları düşük hızlı darbe testleri sonucunda, fiber kırılmasının çok sınırlı olduğunu matris çatlaması ve delaminasyonun ise ana hasar mekanizmaları olduğunu rapor etmişlerdir. Üst tabakalarda matris hasarının esas olarak basınç gerilmesinden, alt tabakalarda ise çekme gerilmesinden kaynaklandığını belirtmişlerdir [19].

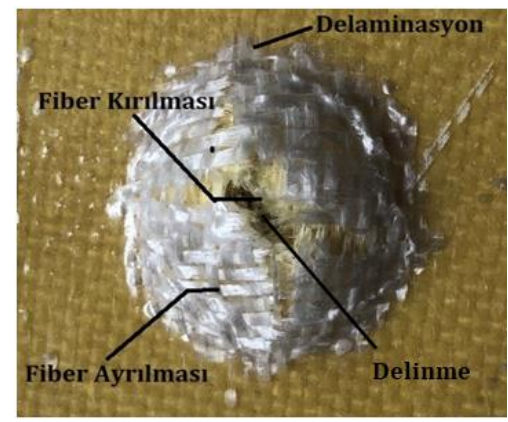

a) Alt yüzey (Cam)

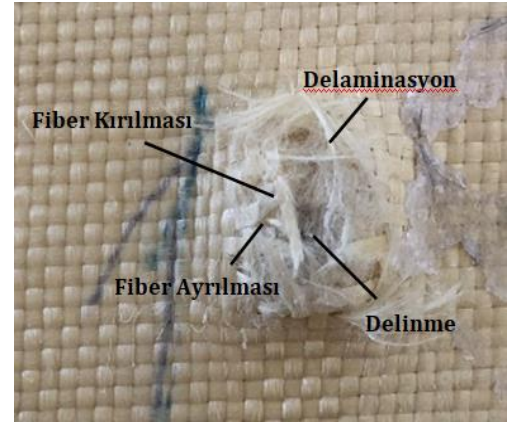

b) Alt yüzey (Kevlar)

Şekil 14. A2S3 numunesine ait alt yüzey hasar fotoğrafları. 
Şekil 14'ten, alt yüzeyin hem kevlar hem de cam olması durumunda her iki elyaf türü için de kompozitte delinme hasar modu oluştuğu ve alt yüzeyin cam olması durumunda oluşan delinmenin (Şekil 14a), alt yüzeyin kevlar olması durumunda oluşan delinmeye (Şekil 14b) göre daha belirgin olduğu görülmektedir. Numunelere darbe uygulanması sonucu alt tabakalarda oluşan eğilme gerilmelerinden dolayı her iki elyaf için de numunelerin alt yüzeyindeki hasar bölgelerinde hem eksen doğrultusunda hem de eksene dik yönde çift yönlü fiber uzamalarının oluștuğu görülmektedir. Ayrıca çoklu fiber ayrılmaları meydana gelmiștir. Eğilmede en fazla çekme gerilmelerinin ve fiberlerin çekme uzama değerlerinin numunenin alt kısmında oluşmasının sonucu olarak da hem kevlar elyaf da hem de cam elyaf alt yüzeyinde fiber ve matris kırılmaları daha da artarak delinme hasar modunu oluşturmuştur.

\section{Tartışma ve Sonuç}

Fonksiyonellendirilmiş alümina ve silika katkılı kevlar-cam elyaf/epoksi reçineli hibrit kompozitlerin kevlar ve cam elyaf yüzeylerine 60J'lük darbe enerjisi ile darbe testi uygulanarak, farklı yüzeylere uygulanan darbe testlerinin darbe davranışı üzerine etkileri deneysel olarak araştırılmış ve aşağıdaki sonuçlar elde edilmiştir:

- Ağırlıkça farklı alümina ve silika katkı oranlarına sahip olan A0S0, A0S5, A2S3, A5S0 hibrit kompozit numuneleri 60J darbe enerjisi altında hasar modları açısından benzer darbe davranışları göstermişlerdir.

- Tüm konfigürasyonlar için 60J darbe enerjisinin hem kevlar yüzeye hem de cam elyaf yüzeye ayrı ayrı uygulanması halinde hibrit kompozit numunelerde benzer hasar modları oluşmuştur. Hem kevlar hem de cam elyaf için numunelerin darbe uygulanan üst yüzeylerinde ezilme ile birlikte matris çatlaklarının oluștuğu görülmüştür. Darbe enerjisinin arttırılmasıyla matris çatlaklarının kompozitin iç tabakalarında ilerleyerek kırılmalara dönüşerek ara yüzeylerde hasar bölgesinin daha da genișlemesine neden olduğu gözlenmiştir. Darbe uygulanmamış olan alt yüzeylerinde ise eğilmeden kaynaklanan çekme gerilmelerinin en fazla olması dolayısıyla fiber uzamaları ve fiber ayrılmaları gözlenmiștir. Darbe enerjisinin arttırılmasıyla en alt yüzeyde oluşan fiber uzamalarının ve hasar bölgesinin daha da genişlediği, dış katmanlardaki matris ve fiberlerin birlikte kırılması sonucu delinme hasar modunun gerçekleştiği görülmüştür.

- Tüm konfigürasyonlar için darbe uygulanmayan alt yüzeydeki deformasyon alanının darbe uygulanan üst yüzeydeki deformasyon alanına göre daha büyük olduğu görülmüştür.
- 60J darbe enerjisi uygulanan 4 grup hibrit kompozitlerin tamamında hem kevlar hem de cam elyaf yüzeye uygulanan darbe deneyi sonucu elde edilen kuvvet-çökme (F-d) grafiklerinde açık tip eğri oluşmuş ve tüm numunelerde delinme meydana gelmiştir.

- Tüm konfigürasyonlar darbe dayanımı açısından karşılaştırıldığında; hem alümina hem de silika içeren A2S3 kompozit konfigürasyonunun darbe dayanımının diğer konfigürasyonlara göre daha iyi olduğu görülmüștür. 60J darbe enerjisi altında konfigürasyonlarda oluşan maksimum darbe yükü açısından sıralama A2S3 > A0S0 > A0S5 > A5S0 şeklinde oluşmuştur.

- Konfigürasyonlarda oluşan çökme açısından sıralamanın A2S3 > A0S0 > A0S5 > A5S0 şeklinde olduğu görülmüştür. Buradan görüldüğü üzere 60J darbe enerjisi için en fazla çökme \%2 alümina \%3 silika içeren A2S3 konfigürasyonunda oluşurken, en az çökme ise $\% 5$ alümina $\% 0$ silika içeren A5S0 konfigürasyonunda oluşmuştur.

- Tüm konfigürasyonlar için cam yüzeyde oluşan hasar alanının kevlar yüzeyde oluşan hasar alanına göre daha büyük olduğu gözlemlenmiștir.

- Tüm konfigürasyonlar için darbe deneyi sonucu kevlar yüzeye darbe uygulanması halinde oluşan maksimum kuvvet değerinin, cam elyaf yüzeye darbe uygulanması halinde oluşan maksimum kuvvet değerinden daha yüksek olduğu görülmüştür. Buradan hareketle, kevlar yüzeye darbe uygulanan numunelerin yük taşıma kapasitelerinin ve darbe dayanımlarının cam elyaf yüzeye darbe uygulanan numunelere göre daha yüksek olduğu sonucuna varılmıştır.

Elde edilen bu sonuçlar doğrultusunda; fonksiyonellendirilmiş alümina ve silika katkılı kevlar-cam elyaf/epoksi reçineli hibrit bir kompozitte, kevlar yüzeyin darbe dayanımının cam yüzeye göre daha iyi olduğu görüldüğünden eğer hibrit kompozit darbeye maruz kalacaksa darbenin kevlar yüzeye uygulanması tercih edilmelidir. Bunun yanısıra alümina ve silika katkıları açısından bir değerlendirme yapılacak olursa; tasarlanan 4 konfigürasyon içerisinde alümina ve silikanın birlikte kullanıldığı hibrit kompozitlerin darbeye maruz bırakılmaları daha uygun olacaktır. Alümina ve silika katkılı kompozitlerin üretiminde bu katkı maddelerinin malzeme içerisinde homojen dağılımının sağlanması da darbe yüküne maruz kalan kompozitin dayanımı açısından büyük önem arzetmektedir. Eğer katkı maddelerinin matris içerisinde ayrışarak homojen bir şekilde dağılımı sağlanamazsa topaklaşmalar oluşacaktır. Malzemenin iç yapısındaki bu topaklaşmalar darbe esnasında yükün homojen dağllımına engel olacağından kompozitin darbeye karşı dayanımı azalacaktır. $\mathrm{Bu}$ nedenle kompozit üretiminde bu hususun da göz önünde bulundurulması önemlidir. 


\section{Teşekkür}

Fonksiyonellendirilmiș alümina ve silika katkılı hibrit kompozit malzemelerin üretimi aşamasındaki katkılarından dolayı Dr. Mehmet Fahri SARAÇ'a, darbe deneylerinin yapılmasındaki katkılarından dolayı Süleyman Demirel Üniversitesi Yenilikçi Teknolojiler Araştırma ve Uygulama Merkezi'ne teşekkürlerimizi sunarız.

\section{Etik Beyanı}

Bu çalışmada, "Yükseköğretim Kurumları Bilimsel Araștırma ve Yayın Etiği Yönergesi" kapsamında uyulması gerekli tüm kurallara uyulduğunu, bahsi geçen yönergenin "Bilimsel Araştırma ve Yayın Etiğine Aykırı Eylemler" başlığı altında belirtilen eylemlerden hiçbirinin gerçekleștirilmediğini taahhüt ederiz.

\section{Kaynakça}

[1] Okutan Baba, B., Karakuzu, R. ed. 2014. Kompozit Malzeme Mekaniği, Efil Yayınevi, Ankara, 471s.

[2] Abrate, S. 2001. Modeling of Impacts on Composite Structures. Composite Structures, 51, 129-138.

[3] Datta S., Krishna, A.V., Rao, R.M.V.G.K. 2004. Low Velocity Impact Damage Tolerance Studies on Glass-Epoxy Laminates-Effects of Material, Process and Test Parameters. Journal of Reinforced Plastics and Composites, 23(3), 327345.

[4] Morais, de W. A. Monteiro, S.N., d'Almeida J.R.M. 2005. Effect of the Laminate Thickness on the Composite Strength to Repeated Low Energy Impacts. Composite Structures, 70, 223-228.

[5] Öndürücü ,A., Karacan, A. 2018. Tabakalı Cam Elyaf/Epoksi Kompozitlerin Darbe Davranışının Deneysel Olarak İncelenmesi. Mühendislik Bilimleri ve Tasarım Dergisi, 6(3), 435-447.

[6] Hosur, M.V., Adbullah, M., Jeelani, S. 2005. Studies on the Low-Velocity Impact Response of Woven Hybrid Composites. Composite Structures, 67, 253-262.

[7] Baucom, J.N., Zikry, M.A. 2005. Low Velocity Impact Damage Progression in Woven E-Glass Composite Systems. Composites, 36, 658-664.

[8] Valença, S.L., Griza, S., Oliveira V.G., Sussuchi, E.M., Cunha, F.G.C. 2015. Evaluation of the Mechanical Behavior of Epoxy Composite Reinforced with Kevlar Plain Fabric and Glass/Kevlar Hybrid Fabric. Composites Part B: Engineering, 70, 1-8.
[9] Rafiq, A., Merah, N., Boukhili, R., Al-Qadhi, M. 2017. Impact Resistance of Hybrid Glass Fiber Reinforced Epoxy/Nanoclay, Polymer Testing, 57, 1-11.

[10] Reis, P.N.B., Ferreira J.A.M., Santos P., Richardson M.O.W., Santos J.B. 2012. Impact Response of Kevlar Composites with Filled Epoxy Matrix. Composite Structures, 94(12), 3520-3528.

[11] Öner, G., Ünal, H.,Y., Pekbey, Y. 2017. Karbon Nanotüp Katkılı Cam Lifi - Epoksi Kompozitlerin Termal ve Eğilme Özelliklerinin Araştırılması. Dicle Üniversitesi Mühendislik Fakültesi Mühendislik Dergisi, 8(4), 805-816.

[12] Mahdi, T.H., Islam, M. E., Hosur, M.V., Jeelani, S. 2017. Low-Velocity Impact Performance of Carbon Fiber-Reinforced Plastics Modified with Carbon Nanotube, Nanoclay and Hybrid Nanoparticles. Journal of Reinforced Plastics and Composites, 36(9), 696-713.

[13) Sayman, O., Benli, S., Arman, Y., Doğan, T. 2009. Karbon cam lifi hibrit kompozit malzemelerin farklı ortam koşulları altında düşük hızlardaki darbe dirençlerinin geliştirilmesi. Tübitak Projesi, Proje No: 107M332, 81s, İzmir.

[14] Park, R., Jang, J. 2001. Impact Behavior of Aramid Fiber/Glass Fiber Hybrid Composites: The Effect of Stacking Sequence. Polymer Composites, 22(1), 80-89.

[15] Park, R., Jang, J. 2000. Effect of StackingSequence on the Compressive Performance of Impacted Aramid Fiber-Glass Fiber Hybrid Composite. PolymerComposites, 21(2), 231-237.

[16] Can, G. 2019. Fonksiyonellendirilmiş alümina ve silika katkılı cam-kevlar elyaf/epoksi hibrit kompozitlerin darbe davranışlarının incelenmesi. Süleyman Demirel Üniversitesi, Fen Bilimleri Enstitüsü, Yüksek Lisans Tezi, 99s, Isparta.

[17] Sayer, M. 2009. Hibrit kompozitlerin darbe davranışlarının incelenmesi. Pamukkale Üniversitesi, Fen Bilimleri Enstitüsü, Doktora Tezi, 134s, Denizli.

[18] Ceyhun, V., Turan, M. 2003. Tabakalı Kompozit Malzemelerin Darbe Davranışı. Mühendis ve Makine, 44(516), 35-41.

[19] Lou, X., Cai, H., Yu P., Jiao, F., Han, X. 2017. Failure Analysis of Composite Laminate under Low-Velocity Impact Based on Micromechanics of Failure. Composite Structures, 163, 238-247. 